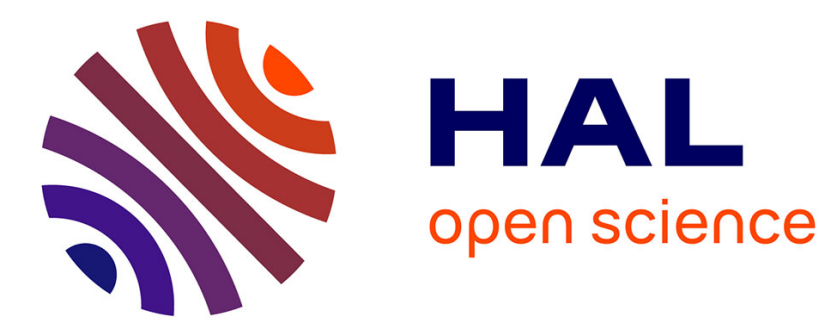

\title{
In Situ Growth of Polycrystalline Bismuth-iron-Garnet Films on Quartz Glass Substrate
}

\author{
T. Okuda, A. Kudoh, S. Yoshihara, N. Adachi, H. Ohsato
}

\section{To cite this version:}

T. Okuda, A. Kudoh, S. Yoshihara, N. Adachi, H. Ohsato. In Situ Growth of Polycrystalline Bismuthiron-Garnet Films on Quartz Glass Substrate. Journal de Physique IV Proceedings, 1997, 07 (C1), pp.C1-707-C1-708. 10.1051/jp4:19971287 . jpa-00255000

\section{HAL Id: jpa-00255000 https://hal.science/jpa-00255000}

Submitted on 1 Jan 1997

HAL is a multi-disciplinary open access archive for the deposit and dissemination of scientific research documents, whether they are published or not. The documents may come from teaching and research institutions in France or abroad, or from public or private research centers.
L'archive ouverte pluridisciplinaire HAL, est destinée au dépôt et à la diffusion de documents scientifiques de niveau recherche, publiés ou non, émanant des établissements d'enseignement et de recherche français ou étrangers, des laboratoires publics ou privés. 


\title{
In Situ Growth of Polycrystalline Bismuth-iron-Garnet Films on Quartz Glass Substrate
}

\author{
T. Okuda, A. Kudoh, S. Yoshihara, N. Adachi and H. Ohsato \\ Section of Inorganic Materials, Department of Materials Science and Engineering, Nagoya Institute of \\ Technology, Gokiso-cho, Showa-ku, Nagoya, 466, Japan
}

\begin{abstract}
Polycrystalline $(\mathrm{Bi}, \mathrm{Gd})_{3}(\mathrm{Fe}, \mathrm{Ga})_{5} \mathrm{O}_{12}$ garnet layer was prepared on a quartz glass substrate at $500^{\circ} \mathrm{C}$ by alternating reactive ion beam sputtering using two ceramic targets, $\mathrm{Gd}_{3} \mathrm{Ga}_{5} \mathrm{O}_{12}$ and $3 \mathrm{Bi}_{2} \mathrm{O}_{3}-5 \mathrm{Fe}_{2} \mathrm{O}_{3}$. The lattice constant was $12.548 \AA$. The layer was almost magnetically compensated and paramagnetic. On that layer, polycrystalline $\mathrm{Bi}_{3} \mathrm{Fe}_{5} \mathrm{O}_{12}$ garnet layer was epitaxially grown by reactive ion bearn sputtering. Those two layers were successively deposited in the same apparatus.
\end{abstract}

\section{INTRODUCTION}

Pure Bismuth Iron Garnet (BIG) is a magnetically soft material which shows giant Faraday effect[1,2]. Polycrystalline BIG $(p-B I G)$ is an attractive material from the viewpoints of magnetooptical recording or microwave applications. BIG is a metastable phase which is only obtainable in a film state by direct epitaxial growth from the vapor phase onto a substrate with the garnet stucture. It decomposes at about $600^{\circ} \mathrm{C}$. The $p$-BIG can be epitaxially grown at $500^{\circ} \mathrm{C}$ on the layer of polycrystalline garnet such as YIG or GGG prepared on a quartz glass $\left(a-\mathrm{SiO}_{2}\right)$ substrate[3]. Those layers act as the substrate for $p$-BIG are usually prepared by crystallization of the amorphous layer deposited at room temperature or by direct deposition of polycrystalline film at high temperatures in oxidizing atmosphere. The crystallization temperatures $\left(T_{c r y}\right)$ of YIG and GGG layers are 800 and $1000^{\circ} \mathrm{C}$, respectively. Gomi et al, found that crystallization during sputter-deposition of highly Bi-substituted iron garnet took place as low as $500^{\circ} \mathrm{C}[4]$. For the purpose of in situ growth of $p$-BIG on an $a$-SiO ${ }_{2}$ substrate, we examined low temperature synthesis of polycrystalline garnet substrate layer of bighly Bi-substituted GGG ( $p$-BGGG).

\section{EXPERIMENTAL}

For the preparation of $p$-BGGG layer, we employed an altermating reactive ion beam sputtering technique. Two ceramic targets, $\mathrm{T}_{\mathrm{A}}$ (GGG) and $\mathrm{T}_{\mathrm{B}}\left(\mathrm{BlG}=3 \mathrm{Bi}_{2} \mathrm{O}_{3}-5 \mathrm{Fe}_{2} \mathrm{O}_{3}\right.$ ) were sputtered alternately using Ar ion beam. An $a$-SiO ${ }_{2}$ substrate was kept in $\mathrm{O}_{2}$ gas flow which act as the reactive atmosphere. Sputtering time in one period for respective targets, $t_{A}$ and $t_{B}$, and substrate temperature were taken as the parameters. Deposition rate was $10 \AA / \mathrm{min}$ in average. Sputtering conditions are summarized in Table 1. The films were examined using X-ray diffractometer (XRD), atomic force microscope (AFM) and vibrating sample magnetometer (VSM).

Table 1 Sputtering conditions

\begin{tabular}{lccccc}
\hline sample no. & 1 & 2 & $2 *$ & 3 & 4 \\
substrate material & $a-\mathrm{SiO}_{2}$ & $a-\mathrm{SiO}_{2}$ & $a-\mathrm{SiO}_{2}$ & $a-\mathrm{SiO}_{2}$ & sample 2* \\
$\begin{array}{l}\text { sputtering time: } \mathrm{t}_{\mathrm{A}}(\mathrm{GGG}) / \mathrm{t}_{\mathrm{B}}(\mathrm{BIG}) \\
\begin{array}{l}\text { number of repetition of } \\
\text { alternating sputtering (times) }\end{array}\end{array}$ & $20 \mathrm{~s} / 20 \mathrm{~s}$ & $20 \mathrm{~s} / 20 \mathrm{~s}$ & $20 \mathrm{~s} / 20 \mathrm{~s}$ & $10 \mathrm{~s} / 20 \mathrm{~s}$ & $0 / 6 \mathrm{~h}$ \\
$\begin{array}{l}\text { substrate temperature }\left({ }^{\circ} \mathrm{C}\right) \\
\text { material phase of deposited layer }\end{array}$ & 450 & 450 & 100 & 450 & continuous \\
\hline
\end{tabular}




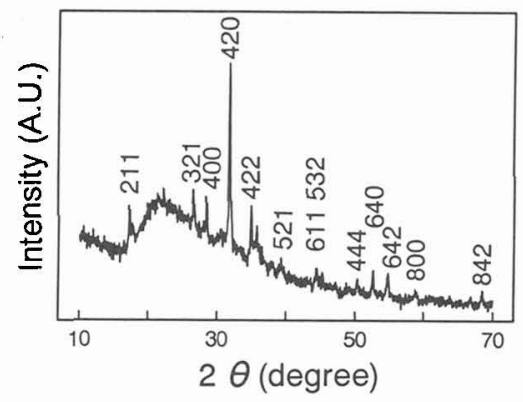

(a)

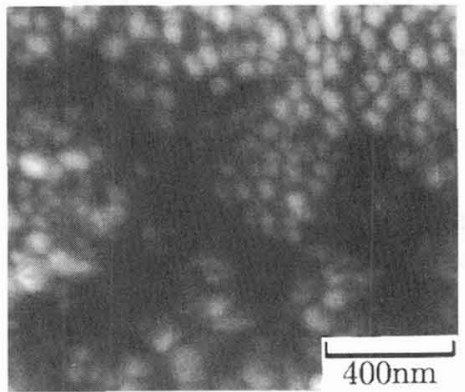

(b)

Fig.1 XRD pattern (a) and AFM image (b) of the sample 2.

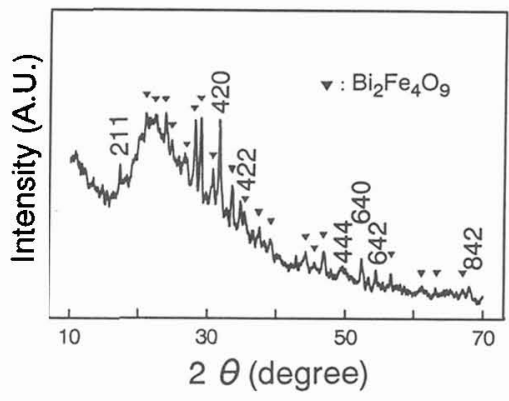

(a)

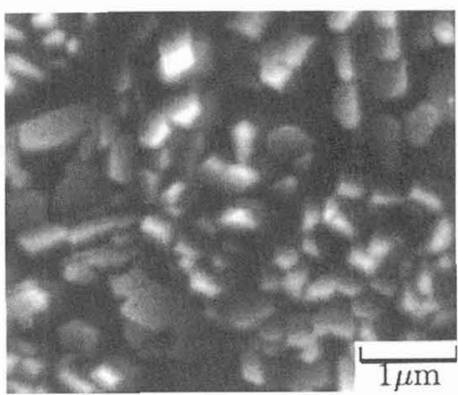

(b)

Fig.2 XRD pattern (a) and AFM image (b) of the sample 4.

\section{RESULTS AND DISCUSSION}

In all the samples, periodical layered structure was not observed. The samples excepting sample 1 crystallized during deposition, which suggests $\mathrm{T}_{\text {cry }}$ of $500^{\circ} \mathrm{C}$ is very critical. In situ growth of single phased garnet was only observed for $t_{A}=t_{B}=20$ s or 40 s, which suggests that homogeneous mixing process of garnet constituent cations at atomic level is requisite for in situ crystallization. In Fig.1(a), XRD pattern of the sample 2 is shown. The layer was assigned as almost single phased garnet. The lattice parameter was $12.548 \AA$ which is slightly larger than the maximum value of $12.540 \AA$ available for thermodynamical iron garnet[5]. The composition analyzed by ICP method was as follows: Bi:Gd:Fe:Ga=1.87:1.24:3.38:1.50. The layer was magnetically compensated and paramagnetic. In Fig.1(b), AFM image of the sample 2 is shown. Both of the primary particles of about $0.04 \mu \mathrm{m}$ in diameter and the secondary particles of about $0.4 \mu \mathrm{m}$ in diameter have rather narrow size distribution. Substitution of $\mathrm{Ga}^{3+}$ for $\mathrm{Fe}^{3+}$ decreases optical absorption. These properties of the sample 2 satisfy the material requisite for the substrate.

The sample 4 was prepared by in situ growth of BIG in succession to growth of the sample $2^{*}$ which was deposited under the same condition for the sample 2. In Fig.2(a), XRD pattern of the sample $2^{*}$ is presented. In the layer, garnet phase and $\mathrm{Bi}_{2} \mathrm{Fe}_{4} \mathrm{O}_{9}$ coexist. The garnet phase was assigned as BIG, because the lattice parameter was 12.62 $\mathrm{A}$. In Fig.2(b), AFM image of the sample 4 is shown. Growth of grain and facet of BIG is remarkable.

\section{References}

[1] Okuda T., Koshizuka N., Hayashi K, Satoh K, Taniguchi H., and Yamamoto H., Digests of 11 th Ann.Conf.Magn.Jpn. $2 \mathrm{aC5}$ and $2 \mathrm{aC6}$ (1988); IEEE Trans.J.Magn.Jpn 3(1988)483; Extended Abstract of 12th Int.Colloq Magn. Films and Surfaces(1985)W1-04.

[2] Okuda T., Katayama T., Kobayashi H., Kobayashi N., Satoh K, and Yamamoto H.,J.Appl.Phys.67(1990)4944.

[3] Okuda T.,Katayama T, Satoh K and Yamamoto H.,J.Appl.Phys. 69, 4580(1991).

[4] Gomi M., Okazaki T., and Abe M.,IEEE Trans.on Magn., MAG-23 (1987)2967.

[5] Espinosa G.P.,J.Chem.Phys. 37(1962)2344. 